\title{
Relationship between Transformational Leadership and Employee Retention among Healthcare Professionals in the United States
}

\author{
Dr. Mouhamadou Sow \\ Faculty, City University of Seattle, Faculty, University of Phoenix, USA \\ DBA, MBA, CFE, CRMA, CTCM
}

Ambroise Ntamon

Professor of Business, El Centro Community College, USA

MBA, DBA(C)

Dr. Rosa Osuoha

Lead Faculty/Area Chair, University of Phoenix, USA

Received: August 5, 2016 Accepted: August 26, 2016

doi:10.5296/ber.v6i2.9831 URL: http://dx.doi.org/10.5296/ber.v6i2.9831

\begin{abstract}
With the endemic health care professional shortage seen both in the United States as well as globally, retaining staff is a high priority. Much like other organizations who rely on human capital, health care professionals are the most important resource for improving patient outcomes, and for achieving organizational performance. Leaders must effectively manage their employees in order to retain top talent and meet organizational goals. One reason for high turnover rates among healthcare professionals is the lack of recognition they are given by their leaders. With this in mind, the purpose of this study was to examine the relationship between transformational leadership components and turnover intentions of health care professionals. One hundred and twenty-seven healthcare professionals from the United States participated in the survey. Participants were recruited through a LinkedIn group of healthcare professionals. More than 100 healthcare professionals from the United States responded to an online survey that contained the Global Transformational Leadership Scale, The Turnover Intention Scale, and demographic questions to describe the sample. A correlational analysis
\end{abstract}


was conducted to determine the type of relationship between the health care professional's perceptions of their supervisors' transformational leadership and their intent to turnover.

The results of this study support the theory of transformational leadership. The health care professionals' turnover intentions were negatively correlated with the transformational leadership components, which indicate that as their turnover intentions increased their positive rating of their supervisors' transformational leadership behaviors decreased.

Keywords: Transformational Leadership, Leadership Styles, Employee Retention, Organizational Commitment, Health Care Professionals, Organizational Strategy.

\section{Introduction}

Retaining employees in many organizations is a significant problem and impacts organizations regardless of their size, location, focus or business strategy (Chitra, 2013). Because employees are the most valuable asset to any organization (Jane, Namusonge, \&Irava, 2012), it is vital that organizations attract and retain employees. Leadership plays a significant part in retaining employees because they have an influence on job satisfaction and employee performance (Parzinger, Lemon, \& McDaniel, 2012). Further, Leaders help shape their follower's attitudes, motivations and behaviors, establish rewards and punishments and are key to retaining the top talented employees (Chitra, 2013). The leader-follower relationship, therefore, is critical (Hughes, Avey, \& Nixon, 2010) and a weak relationship between leader and employee may be a reason for employees to leave the organization.

\subsection{Background}

The healthcare industry is especially vulnerable to employee turnover, specifically among nurses. Nurses are burning out and leaving the nursing profession altogether, which further exacerbates the nursing shortage problem (Cimiotti, Aiken, Sloane, \& Wu, 2012). One of the main reasons for the high turnover rates among healthcare professionals is the lack of recognition as being an important part of the organization (Cimiotti, et al., 2012).

Transformational leaders positively influence their employees (Bass, 1985). Transformational leaders help their employees meet their goals, both personally as well as professionally. Examining transformational leadership style and its effect on intentions to leave the organization in the healthcare industry will provide a better understanding of the healthcare industry employee shortage and allow for the development of potential strategies to mitigate high turnover rates in the healthcare industry.

The cost of employee turnover is immense and adversely impacts organizational morale, performance, and goals (Grissom, 2012). The cost associated with high turnover rates has a major impact, both directly and indirectly. Direct organizational costs include interviewing, training and advertising, which relates to staffing and the process of new employees (Long \& Thean, 2011). The indirect cost of employee turnover is the impact on employee commitment (Wells \& Peachey, 2011). Further, employee turnover may undermine the achievement of organizational goals and decreases in learning and motivation among workers. These issues can indirectly wreak havoc on the credibility and overall performance of the organization 
(Long \& Thean, 2011). These direct and indirect expenses, interruptions in the work process, coupled with turnover rates are significant (Allen, Bryant, \& Vardaman, 2011).

Leaders play a critical role in retaining their employees because of their style of leadership impact whether or not an employee leaves or stays with the organization ( $\mathrm{Ng}$ 'ethe, Namusonge, \& Iravo, 2012). Organizations may be faced with long-term effects if their leaders are not able to mitigate employees' intention to leave or develop ways in which to retain and attract talented employees (Chitra, 2013; Well \& Peachey, 2011).

Wells and Peachy (2011) estimate the direct and indirect costs related to employee turnover to be almost $\$ 11$ billion each year. Awareness of how to manage and mitigate employee turnover rates will provide organizations with resources resulting in employee well-being and organizational effectiveness. Retaining talented and motivated employees are vital to organizational success.

The study results may help leaders in gaining an understanding of the influence of transformational leadership in managing employee retention more effectively. High turnover rates are costly at all organizational levels. Typically, when organizations are unable to retain their employees, the negative impact affects the productivity and services offered by the organization. The study results may further help increase healthcare professionals' awareness of the relationship between transformational leadership components and turnover intentions. It may also provide hiring managers with specific characteristics when looking for employing leaders. The results may also be relevant to leaders and human resources managers who are interested in employee retention, turnover rates, and intention to leave.

The purpose of this quantitative study with a descriptive correlational design was to examine the relationship between transformational leadership style and employee retention among healthcare professional. The sample consisted of 127 participants working in the United States healthcare industry. The objective was to provide information to organizational leaders within the U.S healthcare industry regarding whether promoting transformation leadership is likely to reduce their turnover. The process of achieving this objective included seeking answers to the following questions:

RQ: To what extension does transformational leadership relate to employee retention among U.S Healthcare professional?

The process of answering this research question involved testing the following nulls and alternative hypotheses.

H0a. There is not a statistically significant relationship between transformational leadership and employee retention of healthcare professionals

H1: There is a statistically significant relationship between transformational

leadership and employee retention of healthcare professionals.

\subsection{Theoretical Foundation and Literature Review}

The process of examining the relationship between transformational leadership and employee 
retention in the healthcare professional require a review of current and previous literature related to the two variables. This literature review includes an analysis and synthesis of current and previous literature surrounding the concepts of organizational commitment, leadership styles, transformational leadership, and employee retention.

\subsubsection{Organizational Commitment}

Organizational commitment is defined as "the relative strength of an individual's identification with and involvement in a particular organization (Mowdy, Porter, \& Steers, 1982, p. 27). Leadership has shown to be a significant determining factor to organizational commitment (Mowdy, et al. 1982). Specifically, there is convincing evidence that suggest transformational leadership is positively related to organizational commitment (Bono \& Judge, 2001). Transformational leaders are influential to the levels of organizational commitment of their followers by encouraging them to use critical thinking skills, involving them in the decision-making process, recognizing and appreciating their efforts, and inspiring their loyalty (Bono \& Judge, 2001).

\subsubsection{Leadership Styles}

Leadership is the ability of an individual to influence their followers by guiding, directly, and motivating them to achieve organizational effectiveness. Several leadership styles exist that health care professional managers and leaders adopt in order to lead their staff. One such style is classical leadership. Classical leadership includes autocratic, bureaucratic, situational and laissez-faire. More contemporary leadership styles include charismatic, transformational, connective, shared, and transactional leadership. Bass and Avolio (1990) discovered that transformational leadership styles were preferred over transactional leadership styles among healthcare professionals. Before transformational leadership theory was introduced, transactional leadership was viewed by most leaders as the best style to adopt in organizations leading to effective outcomes (Bass, et al. 2003). Transactional leadership is rooted in a reward approach in which follows are provided with recognition for achieving goals. Under the transactional leadership style, leaders clarify the expectations and standards of performance and followers are punished for not complying with these standards. Further, leaders take on a passive or laissez-faire stance in which they only take action after a problem occurs. Some forms of leadership styles include charismatic leadership, situational leadership, transactional leadership, and transformational leadership. The chosen style leaders use are based on a mix of their values, preferences, and beliefs as well as on the organizational culture and norms.

\subsubsection{Transformational Leadership}

In contrast to transactional leadership, transformational leadership includes "intellectual stimulation, individual consideration, inspirational motivation, and idealized influence" (Bass, 1999, p. 11). The goal of transformation leaders, according to Bass (1999) is to improve the morale and increase the motivation of their followers. When transformational leaders elevate their employee's objectives past their own self-interests, they provide them with the motivation, trust and commitment to complete their tasks (Bass, 1999). 


\section{MInstitute Machink $_{\text {Inthe }}$}

Transformational leaders positively influence their employees (Bass, 1985). Transformational leaders help their employees meet their goals, both personally as well as professionally. Examining transformational leadership style and its effect on intentions to leave the organization in the healthcare industry will provide a better understanding of the healthcare industry employee shortage and allow for the development of potential strategies to mitigate high turnover rates in the healthcare industry.

\subsubsection{Employee Retention}

The main question in the literature regarding employee retention is, "Why do employees leave their organization?" Employees are more apt remain with the organization depending on whether they have a positive relationship with their leaders (Wells \& Peachey, 2011). Also, leadership style is influential on the extent to which employees express their emotional attachment to their workplace (Riaz, Akram, \& Ijaz, 2011). Employees will stay longer within their organization if their leader demonstrates a style of motivation, interest, and concern for their well-being, build trust, provide positive feedback and recognition (Chitra, 2013). These characteristics are consistent with the transformational leadership style components developed by Bass (1985). Jackofsky and Slocum (1987) assert there is a significant correlation between job performance and employee satisfaction and between job performance and the perceptions of supportive leadership. Jackofsky and Slocum (1987) further note that high-performing employees are typically satisfied and optimistic about advancing within the organization.

Leaders help shape their follower's attitudes, motivations and behaviors and also establish rewards and punishments (Chitra, 2013). Leaders are the key to retaining the top talented employees. The leader-follower relationship, therefore, is critical (Hughes, Avey, \& Nixon, 2010). A weak relationship between leader and employee may be a reason for employees to leave the organization. Shukla and Sinha (2013) assert that employees who are happy typically do not leave their job especially when they have a connection with their leader and find fulfillment in the work they do.

Consistent with previous research, more current studies indicate that leadership is influential to employee retention. For example, Chitra (2013) discuss how leadership styles are influential in employees' intention to leave the organization. Intention to leave the organization decreases when followers perceive their leaders demonstrate a style that is favorable in the workplace. Conversely, when employees perceive their leadership style as unfavorable, their intention to leave the organization increases.

The job embeddedness model is premised on the "pull-to-stay" which focuses on factors that make an employee more likely to stay in his or her job. One work-related factor to intent to stay is a positive relationship with leaders (Mitchell \& Lee, 2011). Social exchange theory is used in the context of this study to explain why and in which ways transformational leadership can be used as an important "pull-to-stay" force that deters employees from acting on the intentions to leave an organization. Social exchange theory, according to Blau (1964) assumes an individual's actions are motivated by what they expect to gain from a relationship for their efforts. Social exchange theory is guided by reciprocity in that if reciprocations do 
not occur, the party may withdraw from doing their services.

Two types of social exchange relationships directed at the transformational-turnover relationships are noted in the literature: the supervisor-based exchange (LMX) and the organizational-based exchange (AC) (Lavelle, et al. 2007). Under these two types of social exchange relationships, it is expected that employees can form reciprocal relationships with their supervisors and with their organizational as a whole.

\section{Methodology}

The purpose of this study was to quantitatively determine the extent of a relationship, if any, between transformational leadership and employee retention among the healthcare professional in the United States. The research approach used in this study was a quantitative method with a correlational design. The Global Transformational Leadership Scale, the Turnover Intention Scale (TIS-6), and a demographic questionnaire were used to collect survey data from a random sample of 127 healthcare professionals in the United States. This approach aligns with the purpose of the study, which was to determine the existence of a relationship between transformational leadership and employee retention among the healthcare professional in the United States. This quantitative, correlational study is framed using the social exchange theory.

The goal of this study was to narrow the gap in the literature on voluntary turnover within an organizational setting by examining which components are statistically significantly related to turnover intentions among healthcare professionals. Because the research questions of this study aim to understand the relationship between variables, a quantitative was deemed to be the best method of inquiry for this study. Quantitative methods of inquiry tests objective theories by exploring the relationship between variables (Creswell, 20009). Wells and Peachy (2011), from which this proposed study builds upon, used a quantitative method of inquiry and survey data to examine turnover intention. This study follows a similar method by utilizing a quantitative method of inquiry using descriptive survey data. The study will determine if there is a statistically significant relationship between a specific component of transformational leadership and turnover intentions of healthcare professionals.

\subsection{Population and Sampling}

The setting for this study is multidisciplinary hospitals in the United States. The target population is healthcare professionals. In order to determine the appropriate sample size needed to get a medium effect, a power analysis was conducted using $G^{*}$ Power. The $\mathrm{G}^{*}$ Power is used to calculate sample size and power estimates on three factors using alpha and beta levels and effect size (Cuningham \& McCrum-Gardner, 2007). Small, medium and large effect sizes for hypotheses testing are .o2, .15, and .35 respectively (Cohen, 1988). The G*Power settings selected were based on a priory test of hierarchal multiple regression with three independent, two moderator and one dependent variable and was set to determine the interaction between transformational leadership components and intention to leave. Using settings for $\mathrm{F}$ tests, linear multiple regression with a Fixed model and R2 deviation from zero, it was determined that 85 participants were needed for a medium effect size (Appendix A). 
Alphas were set at .05 and power to detect were set at .80 .

\subsection{Instruments}

To measure transformation leadership, the Global Transformational Leadership Scale was used (Carless, Wearing, \& Mann, 2000). This instrument uses seven-items on a 6 point Likert scale ranging from 1 disagree strongly to 6 agree strongly on leadership behavior measures. Exploratory and confirmatory factor analysis demonstrated that the Global Transformational Leadership Scale measured a single construct of leadership. The instrument also demonstrated satisfactory reliability.

\subsection{Reliability and Validity}

Convergent and discriminate validity of the Global Transformational Leadership Scale were demonstrated using confirmatory factor analysis to test the psychometric properties (Bass \& Avolio, 2004). The reliability of the scales ranged from .74 to .80. This scale was chosen for its clear one-dimensionality and its brevity. The sevens items of the Global Transformational Leadership Scale represent a global measure of transformational leadership. The seven items of the scale yield an alpha of .810 presumed reliable at .70 or higher.

Turnover intention was measured using a model developed by Mobley (1982). This instrument uses a 3-item measure using a 5-point Likert scale ranging from 1 (strongly disagree to 5 (strongly agree). Participants were asked to respond to three statements:

- I think a lot about leaving my present job.

- I will probably look for a job in the next year.

- As soon as possible, I will leave the organization.

Reliability for this instrument was demonstrated at 95 (Long et al., 2012). Demographic data related to the participants' age, gender, race and years at the current position were collected via a researcher developed questionnaire (Appendix B).

\subsection{Data Collection}

Data was collected from participants by way of validated instruments. Scores for the transformational leadership measure was calculated by taking the mean of the items. High means indicate healthcare professionals perceive their leaders as having transformational leadership characteristics. Turnover intention was measured by the averaging the three responses of the participants (Appendix C). Using the demographic variables (Appendix D) as moderators, a multiple regression analysis was conducted to determine the best predictor of low intention to leave rates.

\subsection{Data Analysis}

The researcher tested the various assumptions of multiple linear regression to ensure the data were suitable for the statistical analysis. An analysis of standard residuals was performed which indicated that no outliers were present, Std. Residual Min = -2.14, Std. Residual Max = 2.05. Outliers were also assessed by way of assessing Mahalanobis distance values. The result indicated that since the distance values were equal to or exceeded the chi-square 
criterion, no outliers were present. Multicollinearity assumptions were assessed but were not a concern as the VIF values were less than 10 and the tolerance values exceeded 0.1. The Durbin=Watson values were assessed to determine the independence of residual terms. The assumption of independence of errors was demonstrated with a value of 1.61. Standardized residuals were assessed using a scatterplot and indicated the data were appropriately distributed, meeting the assumption or normal distribution. The assumptions of variance and linearity were demonstrated with scatterplots of the standardized predicted values. Descriptive statistics were obtained and indicated that the data met the assumption of non-zero variances of all variables.

Further, all measures were assessed by means, standard deviations, and internal consistency coefficients using Cronbach's with an alpha of .01 as a cutoff for significance testing to mitigate potential type-I errors.

All data were loaded into SPSS for statistical analysis. Pearson's product moment correlation was conducted to determinate if a relationship exists between transformational leadership components and intention to leave. The hypotheses tested at $p<0.05$. Pearson's correlation $r$ was used to test the relationship between study variables. Also, hierarchical regression analysis was conducted to determine the variation of intent to leave, as the dependent variable, on leadership styles that could be explained while controlling for demographic variables and conversely to determine how much of the variation in the level of intent to stay, as the dependent variable, could be explained by leadership styles, while controlling for demographic variables

\section{Summary}

A survey of healthcare professionals was conducted to examine the relationship, if any, between perceptions of transformational leadership and their intentions to leave. The questionnaire contained the Global Transformational Leadership Scale, The Turnover Intention Scale, and demographic questions to describe the sample. A correlational analysis was conducted to determine the type of relationship between the health care professional's perceptions of their supervisors' transformational leadership and their intent to turnover.

\subsection{Results and Discussion}

The purpose of this study was to examine the components of transformational leadership and their relationship to the turnover intentions of healthcare professionals. The main elements of transformational leadership, as described by Bass (1985), are intellectual stimulation, individual consideration, inspirational motivation, and idealized influences. A quantitative method using descriptive data was used because the research question and associated hypotheses aimed to understand the relationship between the variables.

\subsection{Description of the Sample}

One hundred and twenty-seven healthcare professionals from the United States participated in the survey. Participants were recruited through a LinkedIn group of healthcare professionals. Participants completed the surveys via Survey Monkey. Forty-seven percent of 
the respondents were women. Of the 118 participants who responded to the demographic question regarding race, 45\% were African American/Black; 41\% White; 9\% Asian and 5\% Hispanic. In terms of tenure, $28 \%$ indicated being in their present position for over 10 years; $20 \%$ at least 5 years but less than 10 years; $27 \%$ at least 3 years but less than 5 years; $9 \%$ at least 1 year but less than 3 years, and $12 \%$ less than 1 year (Table 1).

Table 1. Description of Sample

\begin{tabular}{|c|c|c|c|c|c|c|}
\hline \multicolumn{7}{|c|}{ Gender } \\
\hline & & Frequency & Percent & Valid Percent & \multicolumn{2}{|c|}{ Cumulative Percent } \\
\hline \multirow{3}{*}{ Valid } & Male & 59 & 45.7 & 46.8 & \multicolumn{2}{|r|}{46.8} \\
\hline & Female & 67 & 51.9 & 53.2 & \multicolumn{2}{|r|}{100.0} \\
\hline & Total & 126 & 97.7 & 100.0 & & \\
\hline \multirow[t]{2}{*}{ Missing } & System & 3 & \multicolumn{2}{|l|}{2.3} & & \\
\hline & Total & 129 & \multicolumn{2}{|l|}{100.0} & & \\
\hline \multicolumn{7}{|c|}{ Race } \\
\hline & & Frequency & Percent & \multicolumn{2}{|c|}{ Valid Percent } & Cumulative Percent \\
\hline \multirow{5}{*}{ Valid } & Black & 53 & 41.1 & \multicolumn{2}{|l|}{44.9} & 44.9 \\
\hline & White & 48 & 37.2 & \multicolumn{2}{|l|}{40.7} & 85.6 \\
\hline & Asian & 11 & 8.5 & \multicolumn{2}{|l|}{9.3} & 94.9 \\
\hline & Hispanic & 6 & 4.7 & \multicolumn{2}{|l|}{5.1} & 100.0 \\
\hline & Total & 118 & 91.5 & \multicolumn{2}{|l|}{100.0} & \\
\hline \multirow[t]{2}{*}{ Missing } & System & 11 & 8.5 & & & \\
\hline & Total & 129 & 100.0 & & & \\
\hline \multicolumn{7}{|c|}{ Tenure } \\
\hline & & & \multirow[t]{2}{*}{ Frequency } & \multirow[t]{2}{*}{ Percent } & Valid Percent & Cumulative Percent \\
\hline \multirow{7}{*}{ Valid } & & & & & & 1.6 \\
\hline & 10 & or more & 37 & 28.7 & 28.7 & 30.2 \\
\hline & At least 1 ye & less than 3 years & 12 & 9.3 & 9.3 & 39.5 \\
\hline & At least 3 yer & t less than 5 years & 35 & 27.1 & 27.1 & 66.7 \\
\hline & At least 5 yea & less than 10 years & 27 & 20.9 & 20.9 & 87.6 \\
\hline & Les & n 1 year & 16 & 12.4 & 12.4 & 100.0 \\
\hline & & & 129 & 100.0 & 100.0 & \\
\hline
\end{tabular}

\section{Descriptive Analysis of the Variables of Interest}

A description of the health care professionals' responses to the survey is presented in Table 2. The variable of interest included turnover intention, and components of transformational leadership.

\subsection{Turnover Intentions}

Turnover intention was measured by three items on the Turnover Intention Scale. The health care professionals responded to each item on a scale from 1 (strongly disagree) to 5 (Strongly agree). Respondents were asked if they will actively look for a new job in the next year, if they often think about quitting and if they probably will look for a new job next year. 


\section{Macrothink}

Business and Economic Research

ISSN 2162-4860

2016, Vol. 6, No. 2

Participant responses indicated that $51 \%$ agree and $22 \%$ strongly agree they often think about quitting; $41 \%$ and $23 \%$ agree and strongly agree they will likely look for a new job in the next year, respectively; $48 \%$ agree and $14 \%$ strongly agree they will probably look for a new job next year.

Table 2. Health Care Professional Response to Intent to Leave Questions

\begin{tabular}{|c|c|c|c|c|c|}
\hline \multicolumn{6}{|c|}{ I often think of quitting my job. } \\
\hline & & Frequency & Percent & Valid Percent & Cumulative Percent \\
\hline \multirow{7}{*}{ Valid } & & 3 & 2.4 & 2.4 & 2.4 \\
\hline & Agree & 65 & 51.2 & 51.2 & 53.5 \\
\hline & Disagree & 5 & 3.9 & 3.9 & 57.5 \\
\hline & Neutral & 15 & 11.8 & 11.8 & 69.3 \\
\hline & Strongly Agree & 28 & 22.0 & 22.0 & 91.3 \\
\hline & Strongly disagree & 11 & 8.7 & 8.7 & 100.0 \\
\hline & Total & 127 & 100.0 & 100.0 & \\
\hline \multicolumn{6}{|c|}{ How likely is it that you will look for a new job in the next year? } \\
\hline & & Frequency & Percent & Valid Percent & Cumulative Percent \\
\hline \multirow{6}{*}{ Valid } & Strongly disagree & 10 & 7.8 & 8.1 & 8.1 \\
\hline & Disagree & 6 & 4.7 & 4.8 & 12.9 \\
\hline & Neutral & 24 & 18.6 & 19.4 & 32.3 \\
\hline & Agree & 54 & 41.9 & 43.5 & 75.8 \\
\hline & Strongly agree & 30 & 23.3 & 24.2 & 100.0 \\
\hline & Total & 124 & 96.1 & 100.0 & \\
\hline Missing & System & 5 & 3.9 & & \\
\hline & Total & 129 & 100.0 & & \\
\hline \multicolumn{6}{|c|}{ I will probably look for a new job next year. } \\
\hline & & Frequency & Percent & Valid Percent & Cumulative Percent \\
\hline \multirow{6}{*}{ Valid } & Strongly disagree & 11 & 8.5 & 8.7 & 8.7 \\
\hline & Disagree & 7 & 5.4 & 5.5 & 14.2 \\
\hline & Neutral & 28 & 21.7 & 22.0 & 36.2 \\
\hline & Agree & 62 & 48.1 & 48.8 & 85.0 \\
\hline & Strongly Agree & 19 & 14.7 & 15.0 & 100.0 \\
\hline & Total & 127 & 98.4 & 100.0 & \\
\hline Missing & System & 2 & 1.6 & & \\
\hline \multicolumn{2}{|r|}{ Total } & 129 & 100.0 & & \\
\hline
\end{tabular}




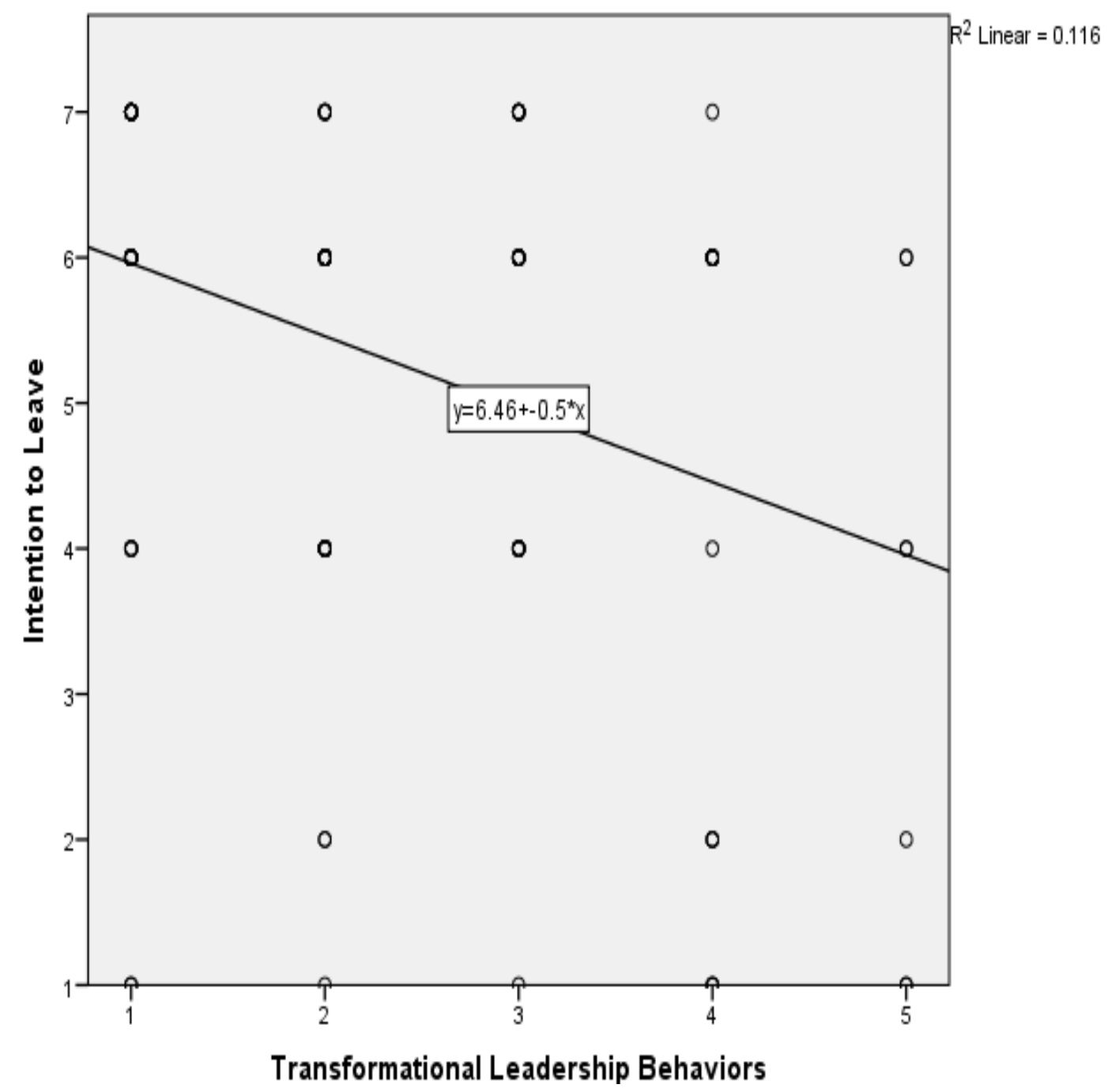

Figure 1. Scatterplot for Standardized Residuals

\subsection{Transformation Leadership Components}

Participants were asked to rate how often their supervisors exhibited specific behaviors on leadership components using a scale ranging from strongly disagree to strongly agree. Participants were asked if supervisors communicate a clear and positive vision of the future in which nearly half of respondents indicated they disagreed or strongly disagreed. Almost $60 \%$ of respondents disagreed or strongly disagreed that their supervisors treat staff as individuals, and support and encourage their development. Over half also strongly disagreed or disagreed that supervisors gave encouragement and recognition to staff. When asked if their supervisors foster trust, involvement and co-operation amongst team members, nearly $65 \%$ indicated disagreement or strong disagreement. Over half of respondents disagreed or strongly disagreed that their supervisor is clear about their values and practices what they preach. When asked if their supervisors instill pride and respect in others and inspires them by being highly competent, again over half either disagreed or strongly agreed (Table 3). 
Table 3. Health Care Professional Responses to Perceptions of Transformational Leadership Questions

\begin{tabular}{|c|c|c|c|c|c|}
\hline \multicolumn{6}{|c|}{ Communicates a clear and positive vision of the future } \\
\hline & & Frequency & Percent & Valid Percent & Cumulative Percent \\
\hline \multirow{6}{*}{ Valid } & Strongly disagree & 23 & 17.8 & 18.1 & 18.1 \\
\hline & Disagree & 33 & 25.6 & 26.0 & 44.1 \\
\hline & Slightly disagree & 42 & 32.6 & 33.1 & 77.2 \\
\hline & Neutral & 23 & 17.8 & 18.1 & 95.3 \\
\hline & Slightly agree & 6 & 4.7 & 4.7 & 100.0 \\
\hline & Total & 127 & 98.4 & 100.0 & \\
\hline \multirow[t]{2}{*}{ Missing } & System & 2 & 1.6 & & \\
\hline & Total & 129 & 100.0 & & \\
\hline \multicolumn{6}{|c|}{ Treats staff as individuals, supports and encourages their development } \\
\hline & & Frequency & Percent & Valid Percent & Cumulative Percent \\
\hline \multirow{6}{*}{ Valid } & Strongly disagree & 37 & 28.7 & 29.6 & 29.6 \\
\hline & Disagree & 38 & 29.5 & 30.4 & 60.0 \\
\hline & Slightly disagree & 26 & 20.2 & 20.8 & 80.8 \\
\hline & Neutral & 17 & 13.2 & 13.6 & 94.4 \\
\hline & Slightly agree & 7 & 5.4 & 5.6 & 100.0 \\
\hline & Total & 125 & 96.9 & 100.0 & \\
\hline \multirow[t]{2}{*}{ Missing } & System & 4 & 3.1 & & \\
\hline & Total & 129 & 100.0 & & \\
\hline \multicolumn{6}{|c|}{ Fosters trust, involvement and co-operation amongst team members } \\
\hline & & Frequency & Percent & Valid Percent & Cumulative Percent \\
\hline \multirow{6}{*}{ Valid } & Strongly disagree & 39 & 30.2 & 31.2 & 31.2 \\
\hline & Disagree & 45 & 34.9 & 36.0 & 67.2 \\
\hline & Slightly disagree & 23 & 17.8 & 18.4 & 85.6 \\
\hline & Neutral & 13 & 10.1 & 10.4 & 96.0 \\
\hline & Slightly disagree & 5 & 3.9 & 4.0 & 100.0 \\
\hline & Total & 125 & 96.9 & 100.0 & \\
\hline \multirow[t]{2}{*}{ Missing } & System & 4 & 3.1 & & \\
\hline & Total & 129 & 100.0 & & \\
\hline \multicolumn{6}{|c|}{ Are clear about his/her values and practices what he/she preaches. } \\
\hline & & Frequency & Percent & Valid Percent & Cumulative Percent \\
\hline \multirow{5}{*}{ Valid } & Strongly disagree & 32 & 24.8 & 25.4 & 25.4 \\
\hline & Disagree & 37 & 28.7 & 29.4 & 54.8 \\
\hline & Slightly disagree & 35 & 27.1 & 27.8 & 82.5 \\
\hline & Neutral & 22 & 17.1 & 17.5 & 100.0 \\
\hline & Total & 126 & 97.7 & 100.0 & \\
\hline \multirow[t]{2}{*}{ Missing } & System & 3 & 2.3 & & \\
\hline & Total & 129 & 100.0 & & \\
\hline
\end{tabular}




\subsection{Correlational Analysis}

Pearson's product moment correlation was used to determine if a relationship exists between turnover intentions and perceptions of transformational leadership. The health care professionals' turnover intentions were significantly and negatively correlated with their perceptions of transformational leadership behaviors of their supervisors. In other words, lower scores on transformational leadership behaviors were related to high scores on intention to leave. Table 4 contains the results of the correlational analysis.

Table 4. Relationship of Turnover Intentions to Transformational Leadership Components

\begin{tabular}{|c|c|c|c|c|c|c|c|c|c|}
\hline \multicolumn{10}{|l|}{ Correlations ${ }^{\mathrm{c}}$} \\
\hline & & $\begin{array}{l}\text { Fosters trust, } \\
\text { involvement } \\
\text { and } \\
\text { co-operation } \\
\text { amongst team } \\
\text { members }\end{array}$ & $\begin{array}{l}\text { Are clear } \\
\text { about } \\
\text { his/her } \\
\text { values and } \\
\text { practices } \\
\text { what } \\
\text { he/she } \\
\text { preaches. }\end{array}$ & $\begin{array}{l}\text { Instills pride } \\
\text { and respect in } \\
\text { others and } \\
\text { inspires me } \\
\text { by being } \\
\text { highly } \\
\text { competent. }\end{array}$ & $\begin{array}{l}\text { I will } \\
\text { probably } \\
\text { look for a } \\
\text { new job } \\
\text { next year. } \\
\end{array}$ & 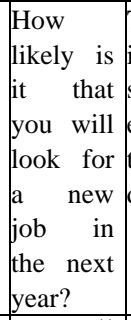 & $\begin{array}{l}\text { Treats staff as } \\
\text { individuals, } \\
\text { supports and } \\
\text { encourages } \\
\text { their } \\
\text { development }\end{array}$ & $\begin{array}{l}\text { Gives } \\
\text { encouragement } \\
\text { and recognition } \\
\text { to staff }\end{array}$ & $\begin{array}{l}\text { Communicates } \\
\text { a clear and } \\
\text { positive vision } \\
\text { of the future }\end{array}$ \\
\hline \multirow{2}{*}{$\begin{array}{l}\text { Fosters trust, } \\
\text { involvement and } \\
\text { co-operation } \\
\text { amongst team } \\
\text { members }\end{array}$} & \begin{tabular}{|l} 
Pearson \\
Correlation \\
\end{tabular} & 1 & $.270^{* *}$ & -.125 & $-.272^{* *}$ & $-.317^{* *}$ & $.433^{* *}$ & $.424^{* *}$ & $.244^{* *}$ \\
\hline & \begin{tabular}{|l} 
Sig. \\
(2-tailed)
\end{tabular} & & .003 & .181 & .003 & .001 & .000 & .000 & .008 \\
\hline \multirow{2}{*}{ 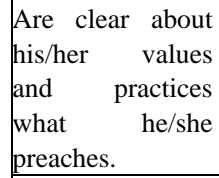 } & \begin{tabular}{|l|} 
Pearson \\
Correlation \\
\end{tabular} & $.270^{* *}$ & 1 & .008 & $-.203^{*}$ & $-.225^{*}$ & $.266^{* *}$ & $.346^{* *}$ & $.223^{*}$ \\
\hline & \begin{tabular}{|l} 
Sig. \\
(2-tailed)
\end{tabular} & .003 & & .933 & .029 & .015 & .004 & .000 & .016 \\
\hline \multirow{2}{*}{$\begin{array}{l}\text { Instills pride and } \\
\text { respect in others } \\
\text { and inspires me } \\
\text { by being highly } \\
\text { competent. }\end{array}$} & $\begin{array}{l}\text { Pearson } \\
\text { Correlation }\end{array}$ & -.125 & .008 & 1 & -.097 & -.031 & .029 & -.070 & .156 \\
\hline & $\begin{array}{l}\text { Sig. } \\
\text { (2-tailed) }\end{array}$ & .181 & .933 & & .300 & .741 & .760 & 453 & .095 \\
\hline \multirow{2}{*}{$\begin{array}{l}\text { I will probably } \\
\text { look for a new } \\
\text { job next year. }\end{array}$} & $\begin{array}{l}\text { Pearson } \\
\text { Correlation }\end{array}$ & $-.272^{* *}$ & $-.203^{*}$ & -.097 & 1 & $.410^{* * *}$ & -.113 & $-.197^{*}$ & $-.323^{* *}$ \\
\hline & $\begin{array}{l}\text { Sig. } \\
\text { (2-tailed) }\end{array}$ & .003 & .029 & .300 & & .000 & .225 & .034 & .000 \\
\hline \multirow{2}{*}{$\begin{array}{l}\text { How likely is it } \\
\text { that you will look } \\
\text { for a new job in } \\
\text { the next year? }\end{array}$} & $\begin{array}{l}\text { Pearson } \\
\text { Correlation } \\
\end{array}$ & $-.317^{* *}$ & $-.225^{*}$ & -.031 & $.410^{* *}$ & 1 & $-.327^{* *}$ & $-.330^{* * *}$ & $-.283^{* *}$ \\
\hline & $\begin{array}{l}\text { Sig. } \\
\text { (2-tailed) }\end{array}$ & .001 & .015 & .741 & .000 & & .000 & .000 & .002 \\
\hline \multirow{2}{*}{$\begin{array}{l}\text { Treats staff as } \\
\text { individuals, } \\
\text { supports and } \\
\text { encourages their } \\
\text { development }\end{array}$} & $\begin{array}{l}\text { Pearson } \\
\text { Correlation }\end{array}$ & $.433^{* *}$ & $.266^{* *}$ & .029 & -.113 & $-.327^{* *}$ & 1 & $.459^{* * *}$ & $.337^{* *}$ \\
\hline & \begin{tabular}{|l} 
Sig. \\
(2-tailed)
\end{tabular} & .000 & .004 & .760 & .225 & .000 & & .000 & .000 \\
\hline \multirow{2}{*}{$\begin{array}{l}\text { Gives } \\
\text { encouragement } \\
\text { and recognition } \\
\text { to staff } \\
\end{array}$} & $\begin{array}{l}\text { Pearson } \\
\text { Correlation }\end{array}$ & $.424^{* *}$ & $.346^{* *}$ & -.070 & $-.197^{*}$ & $-.330^{* * *}$ & $.459^{* *}$ & 1 & $.205^{*}$ \\
\hline & $\begin{array}{l}\text { Sig. } \\
\text { (2-tailed) }\end{array}$ & .000 & .000 & 453 & .034 & .000 & .000 & & .028 \\
\hline \multirow{2}{*}{$\begin{array}{l}\text { Communicates a } \\
\text { clear and positive } \\
\text { vision of the } \\
\text { future }\end{array}$} & $\begin{array}{l}\text { Pearson } \\
\text { Correlation }\end{array}$ & $.244^{* *}$ & $.223^{*}$ & 156 & $-.323^{* *}$ & $-.283^{* *}$ & $.337^{* *}$ & $.205^{*}$ & 1 \\
\hline & $\begin{array}{l}\text { Sig. } \\
\text { (2-tailed) }\end{array}$ & .008 & .016 & .095 & .000 & .002 & .000 & .028 & \\
\hline \multicolumn{10}{|c|}{ **. Correlation is significant at the 0.01 level (2-tailed). } \\
\hline \multicolumn{10}{|c|}{ *. Correlation is significant at the 0.05 level (2-tailed). } \\
\hline
\end{tabular}




\subsection{Discussion, Implications and Recommendations}

The results of this study support the theory of transformational leadership (Bass, 1985). The health care professionals' turnover intentions were negatively correlated with the transformational leadership components, which indicate that as their turnover intentions increased their positive rating of their supervisors' transformational leadership behaviors decreased.

This study supports the findings of others studies that found a correlation between transformational leadership components and intentions to leave in a variety of industries (Hamstra et al. 2011; Pieterse-Landman, 2012; Well \& Peachy, 2011). Because employee turnover is costly to organizations, a practical implication of this study is that supervisors and leaders should strive to build positive relationships with their followers in order to lower employees' intent to leave. The results of this study suggest that negative relationships with leaders may be a key factor in health care workers' intention to leave the organization and search for other employment. This study consisted of health care workers but did not delineate the positions of these workers. Future research should include different levels of health care worker positions to determine if perceptions of leadership behaviors have an impact on intention to leave at all levels. Further, an effort was made to ensure a large sample size and heterogeneity of the participants.

The results of this study were consistent with other studies examining transformational leadership and its relationship to turnover intentions (Hamstra et al. 2011; Pieterse-Landman, 2012; Well \& Peachy, 2011). The key messages from these results are clear. Leaders play an influential role in staff retention. With the shortage of health care professionals in the United States and globally, leaders need to take responsibility and be held accountable to retaining staff. Organizations who strive to build a culture in which leaders exhibit transformational leadership behaviors will likely help mitigate turnover intentions and thus improve the health care shortage endemic.

\section{References}

Allen, D. G., Bryant, P. C., \& Vardaman, J. M. (2010). Retaining talent: Replacing misconceptions with evidence-based strategies. Academy of Management Perspectives, 24(2), 48-64. http://dx.doi.oeg/10.5465/amp.2010.51827775

Bass, B. M., \& Avolio, B. J. (1990). The implications of transactional and transformational leadership for individual, team, and organizational development. Research in Organizational Change and Development, 4(1), 227-239.

Bass, B. M., \& Avolio, B. J. (1993). Transformational leadership and organizational culture. Public Administration Quarterly, 17(1), 112-121.

Carless, S.A., Wearing, A. J., \& Mann, L. (2000). A short measure of transformational leadership. Journal of Business and Psychology, 14, 389-405. http://dx.doi.org/10.1023/A:1022991115523 
Blau, P. M. (1964). Exchange and power in social life. New York: John Wiley.

Cardy, R. L., \& Lengnick-Hall, M. (2011). Will they stay or will they go? Exploring a customer-oriented approach to employee retention. Journal of Business and Psychology, 26(2), 213-217. http://dx.doi.oeg/10.1007/s10869-011-9223-8

Chitra, K. (2013). Role of leaders in employee retention-A pragmatic study with reference to private sector bank employees. International Research Journal of Business and Management, $6,65-74$.

Cimiotti, J. P., Aiken, L. H., Sloane, D. M., \& Wu, E. S. (2012). Nurse staffing, burnout, and health care-associated infection. American Journal of Infection Control, 40, 486-490. http://dx.doi.oeg/10.1016/j.ajic.2012.02.029

Cohen, J. (1988). Statistical power analysis for the behavioral sciences (2nd ed.). New York, NY: Academic Press.

Creswell, J. W. (2009). Research design: Qualitative, quantitative, and mixed methods approaches. Thousand Oaks, CA: Sage.

Cunningham, J. B., \& McCrum-Gardner, E. (2007). Power, effect and sample size using GPower: Practical issues for researchers and members of research ethics committees. Evidence Based Midwifery 5(4), 132-136.

Gill, A., Mathur, N., Sharma, S. P., \& Bhutani, S. (2011). The effects of empowerment and transformational leadership on employee intentions to quit: A study of restaurant workers in India. International Journal of Management, 28(1), 217-229.

Grissom, J. A. (2012). Revisiting the impact of participative decision making on public employee retention: The moderating influence of effective managers. American Review of Public Administration, 42(4), 401-418. http://dx.doi.oeg/10.1177/0275074011404209

Hamstra, M. R. W., Van Yperen, N. W., Wisse, B., \& Sassenberg, K. (2011). Transformational-transactional leadership styles and followers' regulatory focus: Fit reduces followers' turnover intention. Journal of Personnel Psychology, 10(4), 182-186. http://dx.doi.oeg/10.1027/1866-5888/a000043

Hughes, L. W., Avey, J. B., \& Nixon, D. R. (2010). Relationship between leadership and followers quitting intentions and job search behaviour. Journal of Leadership and Organisational Studies, 20, 1-12. http://dx.doi.oeg/10.1177/1548051809358698

Jackofsky, E. F., \& Slocum, J. S. (1987). A causal analysis of the impact of job performance on the voluntary turnover process. Journal of Occupational Behavior, 8(3), 263-270. http://dx.doi.oeg/10.1002/job.4030080307

Jane, M. N., Namusonge, G., \& Iravo, M. A. (2012). Influence of leadership style on academic staff retention in public universities in Kenya. International Journal of Business and Social Science, 3(21), 297-302.

Long, C. S., \& Thean, L. Y. (2011). Relationship between leadership style, job satisfaction 


\section{Macrothink}

Business and Economic Research

ISSN 2162-4860

2016, Vol. 6, No. 2

and employees' turnover intention: A literature review. Research Journal of Business Management, 5(3), 91-100. http://dx.doi.oeg/10.3923/rjbm.2011.91.100

Long, C. S., \& Thean, L. Y. (2012). Employees' turnover intention: A leadership issue?

International Journal of Future Computer and Communication, 1(3), 229-231. http://dx.doi.oeg/10.7763/ijfcc.2012.v1.60

Long, C. S., Thean, L. Y., Ismail, W. K., \& Jusoh, A. (2012). Leadership styles and employees' turnover intention: Exploratory study of academic staff in a Malaysian college. World Applied Sciences Journal, 19(4), 575-581.

Mobley, W. H. (1982). Some unanswered questions in turnover and withdrawal research. $\begin{array}{llll}\text { Academy of } \quad \text { Management } & \text { Review, } & \text { 111-116 }\end{array}$ http://dx.doi.oeg/10.5465/AMR.1982.4285493

Mowday, R. T., Porter, L. W., \& Steers, R. M. (1982). Employee-organization linkages. New York: Academic Press

Ng'ethe J. M., Namusonge, G. S., \& Iravo, M. A. (2012). Influence of leadership style on academic staff retention in public universities in Kenya. International Journal of Business and Social Science, 3(21), 297-302.

Parzinger, M. J., Lemon, M. A., \& McDaniel, K. (2012). The impact of organizational context on turnover and job satisfaction: A multi-analysis study of bank employees. International Journal of Academic Business World, 6(1), 39-50.

Pieterse-Landman, E. (2012). The relationship between transformational leadership, employee engagement, job characteristics and intention to quit. A master's thesis, Stellenbosch University, South Africa.

Riaz, T., Akram, A. U., \& Ijaz, H. (2011). Impact of transformational leadership style on affective employees' commitment: An empirical study of banking sector in Islamabad (Pakistan). The Journal of Commerce, 3(1), 43-51.

Wells, J. E., \& Peachey, J. W. (2011). Turnover intentions-Do leadership behaviors and satisfaction with the leader matter? Team Performance Management, 17(1/2), 23-40. http://dx.doi.oeg/10.1108/13527591111114693 


\section{Macrothink}

Business and Economic Research

ISSN 2162-4860

2016, Vol. 6, No. 2

\section{Appendix A}

$a$ Priori Analysis using G*Power

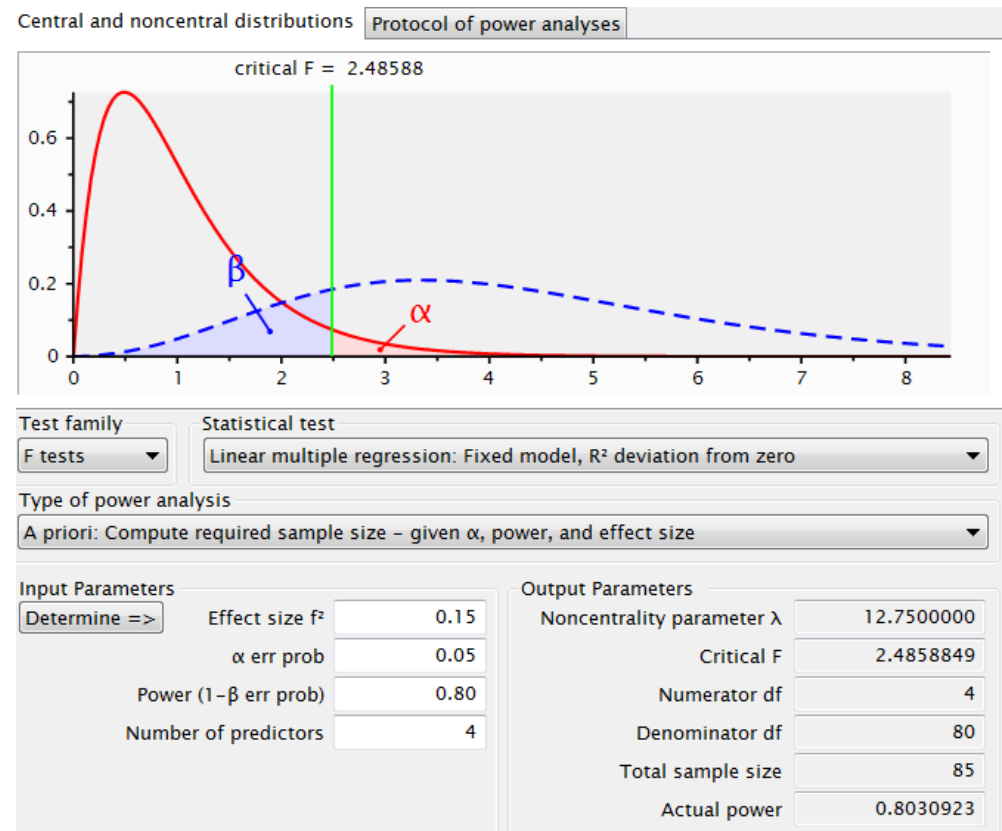

\section{Appendix B}

Global Leadership Instrument

Global Transformational Leadership Scale

(Carless, Wearing \& Mann, 2000)

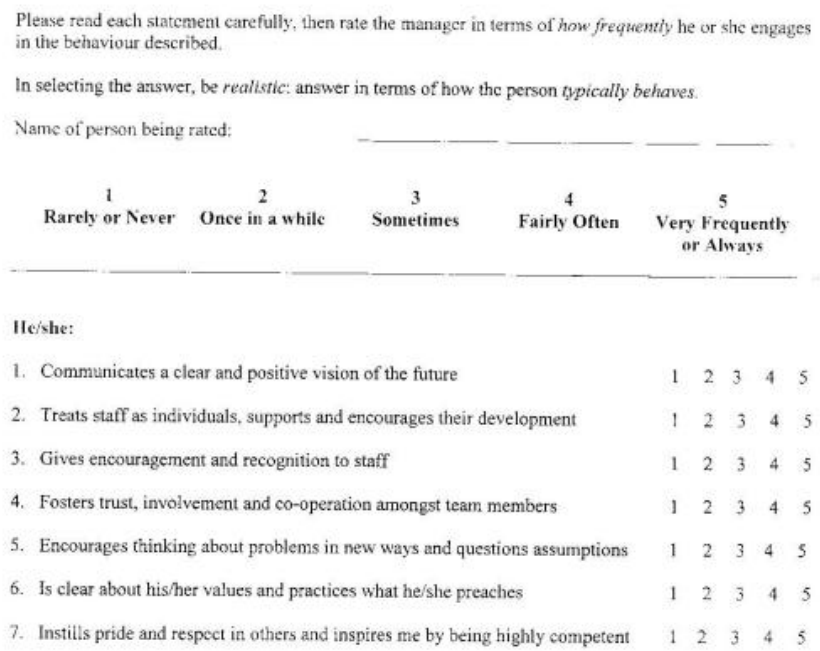


Appendix C

\section{Turnover Intention Scale}

This survey asks you to consider 1 question and 2 statements relating to your intention to leave your organization. Read each statement carefully and then choose a number from 1 to 7 based on the rating scale below that best applies to you and your feelings.

\section{Rating Scales}

- For question 1 , choose a number from the choices below that best applies to the question: 1 = Not At All Likely; 3 = Somewhat Likely; 5 = Quite Likely; 7 = Extremely Likely

- For questions 2 and 3, choose a number that best applies to each of the 2 statements: $1=$ Strongly Disagree $; 2$ = Disagree $; 3=$ Slightly Disagree $; 4=$ Neither Agree nor Disagree $; 5=$ Slightly Agree $; 6$ = Agree $; 7$ = Strongly Agree

Tip: Be as honest and accurate as you can be. Please answer the following questions

1. How likely is that you will actively look for a new job in the next year?

$1=$ Not at all likely

$3=$ Somewhat likely

5=Quite likely

7=Extremely likely

2. I often think about quitting.

$1=$ Strongly Disagree

$2=$ Disagree

$3=$ Slightly Disagree

$4=$ Neither Agree nor Disagree

5= Slightly Agree

$6=$ Agree

$7=$ Strongly Agree

3. I will probably look for a new job next year.

$1=$ Strongly Disagree

2= Disagree

$3=$ Slightly Disagree

$4=$ Neither Agree nor Disagree

$5=$ Slightly Agree

$6=$ Agree

7= Strongly Agree

\section{Appendix D}

Demographic Questionnaire

Answers to the following questions are for descriptive purposes. No information will be used to identify participants.

1. What is your gender?

Female

Male

2. What is your age?

3. What is your race?

White 


\section{Al Macrothink}

Business and Economic Research

ISSN 2162-4860 2016, Vol. 6, No. 2

Black or African American

American Indian or Alaskan Native

Asian

Native Hawaiian or other Pacific Islander

From multiple races

4. How many years have you been employed as a healthcare professional? (Use 1

for experience less than 12 months)

\section{Appendix E}

Permission to use the Michigan Organizational Assessment Questionnaire(MOAQ)-Turnover Scale

From: Yan Fu [mailto:yanfu@umich.edu]

Sent: Tuesday, June 07, 2016 10:22 AM

To: Sow, Mouhamadou T

Subject: Re: Permission to Use The Michigan Organizational Assessment Questionnaire(MOAQ) in my research Study- the Turnover Intention Scale

Dear Mouhamadou Sow,

Thanks for writing. You can use the scale from MOAQ in your research. You don't need a signature from me. Please provide proper citation.

University of Michigan. Survey Research Center. (1975). Michigan organizational assessment package: Progress report II. Ann Arbor: Survey Research Center, Institute for Social Research, University of Michigan.

\section{Appendix F}

Permission to use Global Transformational Scale

From: Leon Mann [mailto:leonm@unimelb.edu.au]

Sent: Wednesday, June 15, 2016 8:57 PM

To: Sow, Mouhamadou T

Cc: Alexander James Wearing

Subject: Global Transformational Scale - Permission

Importance: High

Dear Mouhamadou,

You have my permission to use the GTL scale in your study.

I have attached a copy of the Scale and the 2000 journal article.

Good wishes

Leon Mann 


\section{Mll Macrothink}

Business and Economic Research

ISSN 2162-4860 2016, Vol. 6, No. 2

\section{Appendix G}

Institutional Review Board (IRB)

Certificate of Approval

\section{CityUniversity}

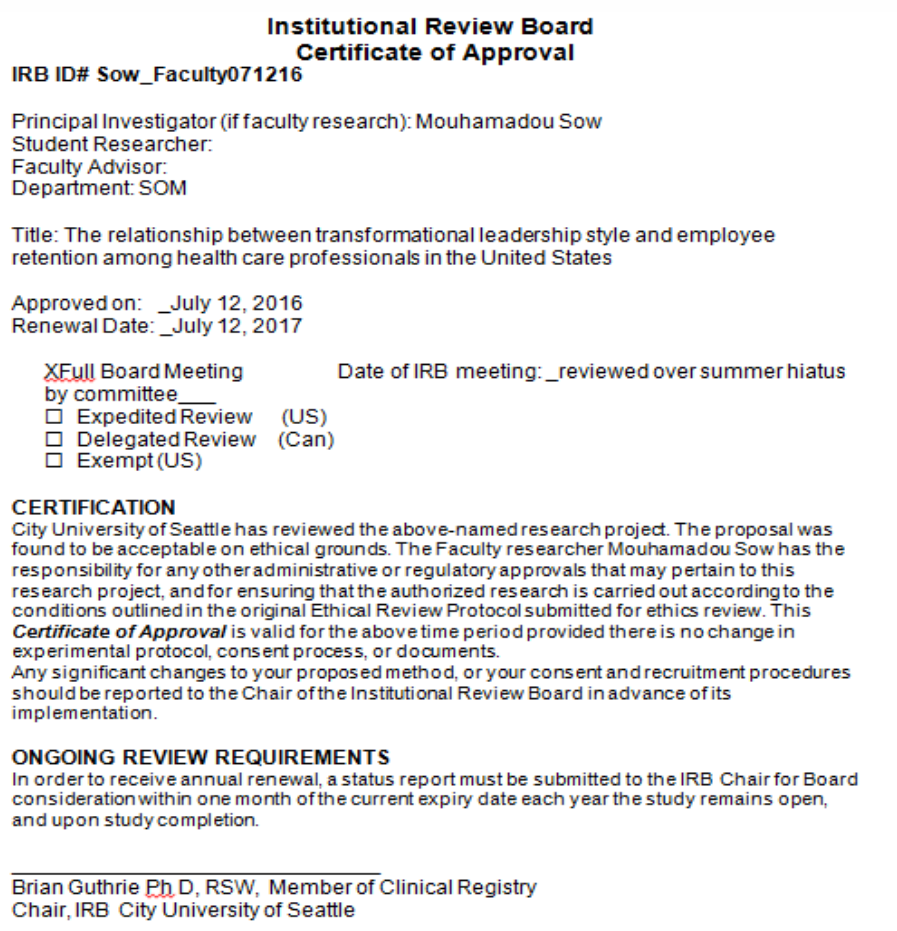

\section{Copyright Disclaimer}

Copyright for this article is retained by the author(s), with first publication rights granted to the journal.

This is an open-access article distributed under the terms and conditions of the Creative Commons Attribution license (http://creativecommons.org/licenses/by/3.0/). 